\title{
PRDM2 wt Allele
}

National Cancer Institute

\section{Source}

National Cancer Institute. PRDM2 wt Allele. NCI Thesaurus. Code C143122.

Human PRDM2 wild-type allele is located in the vicinity of 1 p36.21 and is approximately $125 \mathrm{~kb}$ in length. This allele, which encodes PR domain zinc finger protein 2, plays a role in protein methyltransferase activity. 